\title{
Public Discourses and Migrant Stories of Integration and Inequality: Language and Power in Biographical Narratives
}

\author{
Maja Cederberg, Oxford Brookes University
}

Published in Sociology 2014, Vol. 48(1): 133-149.

\begin{abstract}
This paper considers the role of public discourses in biographical narratives by focusing on discourses of integration and migrant narratives in a contemporary Swedish context. In particular, it explores how public discourses that emphasise migrants' agency and responsibility to 'integrate' help frame the ways in which migrants present themselves. While recognising the importance of biographical research for exploring migrants' experiences and bringing their voices to the fore, the paper argues that we need to pay more attention to how public discourses constrain narratives. It proposes that migrant narratives studied in their social and political context can be used to understand inequalities not only by gaining knowledge of lived experiences of inequalities, but also by considering how dominant discourses help to normalise some of those experiences, and as such may contribute to the reproduction of inequalities.
\end{abstract}

\section{Key words}

Biographical Methods, Discourse, Migrant Narratives, Social Inequalities

\section{Introduction}

The method of biographical interviewing has become increasingly popular in the social sciences, and it aims to explore the experiences of individual subjects in the context of their life trajectories (Harrison 2009, Merrill and West 2009, Roberts 2002, Chamberlayne et al. 2000). An important part of the biographical tradition has been a concern to represent the experiences of marginalised groups (Harrison 2009), which helps to account for the popularity of biographical methods within certain areas of research, including migration studies (e.g. Apitzsch and Souti 2007, Breckner 2007, Findlay and Li 1997, Halfacree and Boyle 1993). Indeed, biographical research provides access to a wealth of information that helps us to better understand the migratory experience, but also to perspectives that add to and at times challenge dominant understandings. For example, biographical accounts can help challenge reductionist discourses of migrants and migration, by presenting alternative knowledge of migrant lives and identities (e.g. Inowlocki and Lutz 2000, Erel 2007). More broadly, narrative and other forms of qualitative research that bring migrants' perspectives to the fore enables a critique of the 'homogenizing constructions of identities' (Yuval-Davis and Kaptani 2009: 58) that frequently constrain their lives and opportunities (see also Eastmond 2007, Lawson 2000, Phoenix 2009). An intersectional approach, which highlights the multiple position/ing of individuals and as such problematizes group-based categorisations, is particularly useful in that regard (Anthias 2002, YuvalDavis and Kaptani 2009). 
While the critical potential of biographical research is important, it is equally important to acknowledge the fact that marginal voices are not necessarily counter-hegemonic. All stories are produced within a social context and are interconnected with other stories (Riessman 2008, Moen 2006, Taylor 2010). This includes dominant accounts of events, and as Goodson (1995: 95) notes, individual narratives often turn out to be 'carriers of dominant messages' (see also Popular Memory Group 1982, Johnson et al. 2004). As such, 'valoriz[ing] the subjectivity of the powerless individual' (Denzin, cited in Goodson 1992: 8, 9), which may follow an aim to represent marginalised voices, can be problematic if the discursive constraints that help shape their accounts are insufficiently explored.

This paper considers the role of public discourses in biographical narratives by analysing discourses of integration and migrant narratives. I draw on my research on migrant incorporation and ethnic inequalities in Sweden, which combined biographical interviews with other methods, including discourse analysis of policy debates and developments surrounding migrant integration, ethnic discrimination and racism. As part of the research, issues of integration and inequality were considered from different angles, and the biographical interviews helped centre the (multi-faceted) migrant subject. By adopting a biographical approach, I was able to examine my interviewees' current positions in relation to their respective backgrounds, through which trajectories, including processes of downward or upward mobility, could be explored. Furthermore, considering how people present different experiences in the context of their life more broadly enables a complex understanding of the meaning-making processes involved. Finally, I hoped that an open interview approach would help me explore relevant factors not encompassed by the restricted and value-charged concepts available, such as 'integration' and 'exclusion'.

The paper begins by considering different approaches to understanding (biographical) narratives, in terms of voice, discourse, power, and the subjects that are expressed or constituted through narratives. I then go on to provide some context for the empirical discussion, after which I explore the role of public discourses of migrant integration and ethnic divisions in migrant narratives, focusing on two case studies. However, whilst focusing primarily on that aspect of the narratives, I will emphasise the multi-faceted and situated nature of narratives, and the importance of considering the interview context, the position/ing of those involved in the research process and the performative aspect of narratives.

\section{Voice, discourse and power in biographical narratives}

Aside from a concern to represent marginal voices, in turn linked to social and political developments from the 1960s onwards, the increased popularity of biographical research has also been explained with reference to a wider shift towards a re-centring of human experience in social science research, 
as well as developments in theories of subjectivity (Merrill and West 2009, Roberts 2002, Rustin 2000, Wengraf et al. 2002, see also Gubrium and Holstein 2002). Importantly, there are different understandings of the latter, as well as different usages of biographical narratives. For example, where some have emphasised agency, others have highlighted the value of biographical narratives for gaining knowledge of the social structures in which the individual is positioned (e.g. Apitzsch and Inowlocki 2000, Bertaux and Kohli 2009, Popular Memory Group 1982, Stanley 1992). Similarly, where some propose that an 'authentic' experience can be accessed through carefully designed interviews (e.g. Rosenthal 2004), others question the idea that it is possible to gain an understanding of events from the 'true' point of view of the biographer (e.g. Atkinson and Delamont 2006, Riessman 2008, Stanley 1992) ${ }^{1}$.

As Riessman (2008: 31) notes, a conception of narratives as co-constructions is widely accepted amongst narrative researchers. This is the conception adopted here, and as such, the conventions shaping the interview, the power relations involved, and the social experience both participants bring with them are all seen to have implications for how narratives develop and are interpreted (Johnson et al. 2004, Phoenix 1994, Plummer 2001, Sangster 2009, Stivers 2009). As all knowledge is situated (Haraway 1991, Stanley 1992), considering the position of those involved in the research is important, although not in terms of a unified or 'finished' identity (Haraway 1991). As Phoenix (1994: 70) argues, 'respondents [and interviewers] are not positioned in any unitary way', which necessitates 'analysis of the ways in which wider social relations enter into the interview relationship', as well as the wider research process, in complex and intersecting ways (see also Anthias 2002). To add further complexity, we may note that audiences are often multiple and imagined beyond the immediate interview situation, and that subjective perceptions of those audiences are important along with their structural location (Davies and Harré 1990, Riessman 2008).

Aside from the inter-personal dynamics involved in the interview and the wider social and power relations implicated in those, emphasising the situatedness of knowledge production also entails a consideration of the wider cultural narratives interviewees draw on when producing their 'own' stories (Moen 2006, Taylor and Littleton 2006, Taylor 2010). Those narratives play an important role in determining what is possible to feel and express about one's situation and experience, by offering a limited set of options and through setting the framework of acceptability or normality (Miller 2005, 2007). Importantly, individuals have differential access to narrative resources and thus may be more or less constrained in their narration, linked, yet again, to their position and the power relations implicated in it (Sangster 2009, Taylor and Littleton 2006, see also Plummer 2001).

Discussing the role of wider cultural narratives and the role of power takes us to the relevance of Foucault's work to the present discussion. Foucault's $(1977,1979,1980)$ insights into how power 
operates through language, by constructing objects of knowledge within various social and institutional settings, have helped us consider how power can function in subtle, uneventful, and even invisible, ways. Foucault suggests that through specific discourses (frameworks of meaning through which we make sense of objects, relations and events), social subjects are positioned by and come to embody different social and power relations. The role of individual subjects is emphasised as they are seen to self-regulate through the process of subjectification (Foucault 1988). At the same time, Foucault emphasises that neither frameworks of meaning nor the power relations to which they are attached are singular, but multiple and intersecting. Similarly, as many researchers have emphasised, (biographical) narratives, along with the subjectivities they present/construct, are not complete or coherent, but multi-faceted (Anthias 2002, Stanley 1992, Tamboukou 2003, Taylor 2010). As such, subjects as well as discourses need to be analysed in a manner that allows for complexity and that highlights tensions and contradictions (see also Johnson et al. 2004).

While I do not have space to engage at length with theoretical debates about subjectivity and the different social processes (and their material and symbolic dimensions) through which individuals develop an identity and a sense of self, it is important to note that a theoretical critique of essence, 'truth' and coherence in regards to the subject does not imply that perceived needs for such essence and coherence do not exist. As Rose (1999) notes in his genealogy of the 'private self' in modern liberal societies, the idea of an autonomous and reflexive self is accepted knowledge about the human subject, which guides our conceptions of ourselves and others, as well as our social practices (including telling stories about ourselves, which, as Taylor and Littleton (2006) emphasise, is constrained by previous 'tellings'). However, rather than a universal definition of subjectivity, Rose argues that this is a historically produced 'truth' linked to particular power relations that make possible certain subjectivities (whilst foreclosing others), normalised through ways of thinking and acting that are simultaneously effects and constitutive thereof (see also Davies 2000). As we shall see, this liberal subjectivity is central to how the two narratives analysed in this paper are constructed.

\section{Public discourse and migrant narratives of inequality and integration}

Since the early 1970s, migration to Sweden has been dominated by refugees and family migrants from different parts of the world (prior to that, labour immigration from Nordic and other European countries was the main influx). During the same period, significant transformations of the labour market took place (from industrial to post-industrial), which had an impact on the labour market position of migrants (Bevelander 1999, 2005, Knocke 1999, 2000). Furthermore, there have been changes in the broader political-economic context, and the long-term dominance of a traditional 'Swedish model' of Social Democracy has since the mid-1980s been re-shaped in line with European and global trends, towards increased dominance of the market combined with reduced welfare support (e.g. Schierup et al., 2006, Schierup and Ålund 2011). 
During the time period when I undertook research for the two projects I draw on here (2001-2008), the topic of 'integration' featured significantly in public and political debates in Sweden. The background to this lies in, on the one hand, an increased focus on alleged problems relating to cultural diversity (especially supposedly fundamental differences between Swedish/Western and 'other' norms and values), and, on the other, patterns of ethnic segregation and social and labour market exclusion of different migrant and minority ethnic groups, which had become prominent political issues. Whether focus was put on one, the other, or both, a common conclusion drawn by critics from both the left and right of the political spectrum was that Swedish integration policy to date had failed, and that a revised approach was needed (e.g. Integrationsverket 2003, SOU 2006:79, Folkpartiet 2004, 2008, see also Cederberg and Anthias 2006a, 2006b, Schierup and Ålund 2011).

The different arguments featuring in debates over integration, segregation and exclusion are set within broader discursive frameworks that conceptualise the causal mechanisms involved in producing integration and divisions differently (by emphasising cultural, socio-economic, individual or structural factors). In turn, those frameworks are underpinned by different conceptions of citizenship and, more broadly, subjectivity. What I am interested to explore here is the extent to which particular discourses impact on individual narratives and experiences of integration and inequality. In the two narratives analysed in the paper, two particular discursive frameworks play a significant role: one that emphasises individual agency and responsibility, and another which problematizes cultural diversity and multicultural policies. While those frameworks far from encompass the entire debate, which, as noted above, contains multiple perspectives, they have come to increasingly dominate it and shape the policy approach adopted.

The paper draws on biographical interviews carried out as part of two research projects. The first was my doctoral research, which aimed to explore the social processes involved in producing inequalities along ethnic lines, partly through examining refugees' biographical narratives, and in particular their experiences of Swedish society (Cederberg 2006). The second was the Swedish component of a crossnational EU-funded project about female migrants' experiences of integration, focused in particular on how different policies either enable or hinder the integration process (Kontos et al. 2009) ${ }^{2}$. The sample is composed of twenty interviews (eight Bosnian, five Somali, three Iraqi, one Eritrean, one Lebanese and two South American interviewees; seven men and thirteen women). All interviewees were refugees or family migrants, the majority between the ages of early $30 \mathrm{~s}$ and early $50 \mathrm{~s}$. The interviews were carried out in and around Malmö, a city located in the south of Sweden and a former industrial centre. With just under 300000 inhabitants, it is the country's third largest city, and with around $30 \%$ of the population being born abroad, one of the most immigrant-dense cities in Sweden. 
The case-study approach was chosen for this paper in order to be able to provide a detailed account of narrative constructions. The two cases discussed do not represent the entire sample but have been chosen because they usefully demonstrate the normalising function of discourse. A number of other narratives displayed similar features, while yet others foregrounded experiences of discrimination and inequality. The nature of the narrative produced follows on from a complex combination of gender, ethnic background, educational level, social class background and migratory history, and in particular the nature and extent of social mobility occurring through migration. Knowledge of Sweden prior to migration and expectations related to particular constructions of Swedish society (centred on equality, democracy and international solidarity) also appeared to play a role, and some interviewees have expressed disappointment when considering their experiences in relation to such constructions ${ }^{3}$. Finally, differential access to critical discourses came across as significant, following on from political affiliations, civic engagement, and exposure to political and academic debates on migration, integration and inequality.

\section{Nina: 'I was always after the language'}

My interview with Nina took place in the summer of 2003, when she was in her early 30s. Nina came to Sweden with her immediate family in 1992, after having fled the conflict in Bosnia. She is married and has two children, and before migrating she was a housewife. She describes her life prior to migrating as 'a complete life ... the big house, the garden, we had everything'. At the time of the interview, Nina worked in a day centre for children and young people, while also studying part-time.

In response to the first, open interview question about her life and migratory trajectory, Nina immediately begins her story by stating the importance of learning the Swedish language:

'I was always after the language. The language for me was something that I just had to learn. Without the language I could not get anywhere. So that was the key for me, something I have to start with and proceed from. I have to know the language if I am to go into society. And that's something negative today: that immigrants don't invest as much into the language as they should.'

Having stated her own concern to learn the language, Nina then goes on to discuss the problem of migrants not doing so, and she points towards people of her own ethnic group, whom she suggests do not make enough effort to 'integrate themselves'. I will come back to this shortly, but remaining for the time being on Nina's personal story of 'integration'. Asked later in the interview about obstacles other than language skills, Nina replies, 
'No, there were no obstacles at all. I think our caseworkers at the jobcentre were the happiest, when we came and told them, that's enough, now we've found jobs. They could only congratulate ... So there's no one who can tell me today that no, I can't find a job, I can't get a job, I'm black, or I wear a veil. It's up to everyone themselves.'

After having presented her own 'success' story, Nina appears to move on to draw the conclusion that because she did not encounter any obstacles, the reporting of any such problems must be untrue. However, she goes on to add that she is aware of having made efforts to get on with people and avoid confrontations.

'I have never had a problem when it comes to this. And I'm very happy about that. But also I know deep inside that I haven't done anything to be suspicious or to feel bullied, or harassed because of my appearance or anything. I mean, I have worked on this myself. Only like when you come into the jobcentre, how you greet people. If you come in and are angry and start shouting "what do you mean, work practice or course", my god, try to talk. Otherwise you won't be welcome anywhere.'

At the same time as she endorses the argument that language is the key to integration, Nina also downplays discrimination as a potential obstacle. However, a closer look at her statement here indicates potential problems that she chooses to downplay: she has decided not 'to be suspicious' or 'feel bullied', whereby she affirms her own efficacy but also leaves open the possibility that some people may feel differently. However, rather than going into any detail, Nina chooses to problematize migrants' behaviour in meetings with Swedish institutions, which she suggests produces hostility. She also condemns what she perceives to be a demanding attitude of certain individuals in their interaction with Swedish authorities.

'Oh yes, you are referred. Oh my god, there's so much rubbish also today, people say "they just send me from course to course, work practice to work practice" - but my god, pull yourself together! ... What annoys me is that grown ups are sometimes worse than children. What do you mean they send you from course to course, are you not an adult? Can you not think for yourself? ... If there is something I have learned in Sweden, it's this: that you don't have to do anything. It's just strong will. If you want, if you have energy, there are no problems at all.'

Although Nina tends to emphasise individual power and responsibility, and provides an account of events that problematizes migrants' behaviour rather any obstacles they may encounter, we have already seen allusions to potential problems that she chooses to downplay. A good example of where 
her account indicates problems can be found in the part of her narrative where she reflects upon the area where she lives:

'You can see what is missing in this area. There are not many Swedes living here. There are older pensioners, and social cases, those sorts of families. The 'real' families, the 'healthy' families, they don't live here.'

Her account of residential segregation notes both a broader social/class dimension as well as an ethnic one, and this part of her narrative reflects a much-debated problem in Sweden, namely a pronounced ethnic segregation. This theme comes back at other points in Nina's narrative, when she reflects upon tendencies of different groups to 'close themselves in', referring to examples as wide-ranging as gated communities and migrant associations.

'If I could, I would close down all immigrant associations. I think they lead to separation. Segregation is a huge problem, and I think these associations are part of that problem ... and it is not at all strange. This is what we could have expected. After all the possibilities people have got here. Of course they having taken their share and closed themselves in.'

Considering these points in relation to one another, we see that Nina's analysis of ethnic segregation puts the focus on migrant individuals and communities. It appears as though she finds the problem to lie in a combination of the possibilities people have been given (by the Swedish state) and the ways in which these have been abused (by migrants).

As such, while Nina acknowledges problems, she presents them primarily as created by migrants rather than as structural obstacles faced or experienced by migrants. At the same time, there are tensions and contradictions in Nina's narrative: places where she either alludes to or gives an account of factors that could be read in terms of discrimination and/or structural constraints. However, rather than allowing the contradictions to remain as such, Nina tends to resolve them by emphasising, on the one hand, her own strength and determination, and, on the other, the general responsibility of migrants to overcome segregation and exclusion.

\section{Anita: 'I have to show that not all immigrants are bad'}

Anita is from Venezuela, and came to Sweden in 2005 to live with her Swedish partner, whom she met when she was studying in Spain. My interview with Anita took place in spring 2007, when she was in her early $30 \mathrm{~s}$, and at that time she was working part-time as a cleaner and part-time teaching Spanish. Anita had a professional career before migrating, and is concerned to resume that in Sweden in due course. 
If Nina's narrative starts by emphasising the importance of learning the language, Anita's account of life in Sweden starts with a description of how she 'feels borrowed': not being at home, and feeling a pressure to perform impeccably as a result. She speaks of this in particular in regards to looking for work, and being concerned about not doing a job properly: 'I'm not Swedish, I have to do everything right, correctly. If I'm going to work, I have to work in the right way'. In relation to this, Anita mentions migrants with a different attitude, who she thinks abuse the welfare system. She says she met people like that on her Swedish language course.

'I have come across several people who are here just to get money, get benefits ... there are some people, there was, I don't know if they still are, who have been at (language classes) for four years ... to learn a language in four years, if you live here in the country? ... why four years? Because if you study (language classes), you get money from the government, you get benefits...'

Aside from abusing the welfare state, Anita suggests that migrants also abuse the term discrimination, and refuse to take responsibility for their situation. She argues that migrants need to make efforts and should not expect to be served things 'on a plate'. She also suggests that some migrants misread things as discrimination, based on their lack of self-criticism and/or Swedish language skills. She thinks you need to be careful when speaking about discrimination and says she has come across lots of migrants who are quick to judge actions as discriminatory. She refers to the word 'blatte' (a derogatory word for an immigrant or ethnic minority person), and asks what does it mean: someone who comes from another country, so when you get called this, why feel discriminated against?

'I met many people who say ... "they call me blatte". And then if you think, ok ... what is a blatte: a person who comes from another country. Of course, I come from another country. But why do I have to feel discriminated against when people call me immigrant? Yes, I'm an immigrant (laughs mildly), what should I say?'

Of course, the word 'blatte' is not a neutral, descriptive word, but a very negatively loaded word. The way in which Anita chooses to interpret the word as well as people's reactions to it signifies her reluctance to understand certain encounters as hostile, and her tendency to question claims about discrimination rather than the events to which they refer.

When talking about her social life, Anita similarly juxtaposes her own approach to 'integration' to what she perceives to be the case of (some) other migrants. She emphasises the importance of having 
Swedish friends, and says she thinks that it is a shame that some people only have friends from their own country. Rather than being excluded, she suggests that they are excluding themselves.

'And um for example when I look at different groups ... there is some difference, that they only get friends from their own country, and they do not know Swedish, they cannot go into society. And then they say they feel discriminated against, so that I think it is a self-discrimination. OK, you make your own ghetto, and then you say ah, it is your fault.'

At the same time, Anita seems to find it rather difficult to make Swedish friends herself. She says that all her friends are from South America, and thinks that this has to do with the fact that Swedish society is rather closed in (a factor unaccounted for in her discussion of migrants who she suggests exclude themselves). This points towards a tension in her narrative: she recounts experiencing problems in making friends with Swedish people, but nonetheless blames other migrants for only socialising within their own ethnic groups.

Another tension in Anita's narrative relates to her condemnation of migrants who abuse the Swedish welfare state, whilst nevertheless pointing out that people tend to make generalisations about the wider migrant population on the basis of a few isolated incidents: 'It is not so good that, when one immigrant does, two immigrants do something bad, that you speak generally. That is hard.' We see here that at the same time as Anita reproduces certain negative discourses about migrants, she emphasises the effects of (racist) stereotypes. However, she later proposes that the solution to this is for her to behave well and show that not all immigrants are bad.

'I still feel it's not my, my home, and I have to have a good behaviour, you could say, because I'm not from here, so I have to show that not all immigrants are that bad ... So it's a little task that I have, or that I feel that I have ... if everyone says that all immigrants are bad, I'm going to do good, because if someone knows me - ah, but she's immigrant also, so not all are bad.'

Another example of a similar logic in Anita's narrative relates to her emphasis on having a job, which was noted earlier. While to some extent portrayed as her general view, it also appears that social pressures are implicated in this. Notably, she felt a lack of respect from her boyfriend's friends before she found a job.

'Here in Sweden I think, it's my impression, that all people respect that you work, with anything, but you work ... when I came here to Sweden and met my boyfriend's friends, and they asked oh, what do you do? I study, Swedish. Ah, but don't you work? No - and 
then they turned ... first I thought oh, how rude, I thought, but then I understood, OK, I understand why. Because all people pay taxes, and if I don't work, I use for example, I can go to the hospital and use everything, I have all the benefits, without paying tax ... And then I found a job, and everyone "oh, Anita found a job, how good" (laughs).'

As we have seen, social pressures on migrants to be 'good' and behave well are clear at several points in Anita's narrative. At the same time as she reproduces certain discourses and stereotypes in her narrative, you can notice the burdensome aspect in how she thinks she needs to do everything correctly while also 'proving' that not all migrants are 'bad'. Furthermore, the fact that she has taken up employment beneath her level of education and skill is noteworthy and could to some extent be seen as an example of how social pressures, related to particular expectations as well as assumptions about different groups, may have implications on behaviour. While no direct causal links are possible to establish, it seems important here to highlight the interplay of narrative, discourse and actions.

\section{Integration, autonomy and the responsible citizen: normalising functions of public discourse}

As we have seen, both interviewees criticise migrants who fail to make efforts to 'integrate', by not learning the Swedish language or by 'closing themselves in'. As such, they reproduce a discourse that makes migrants responsible for ethnic divisions and lack of 'integration' in society. Nina makes a link to multicultural policies by suggesting that migrants have abused opportunities (for co-ethnic engagement) they have been granted by the Swedish state, and isolated themselves, while Anita claims that migrants produce their own exclusion by failing to engage with people outside of their own ethnic groups.

Since the 1980s, similar debates on multiculturalism have resulted in growing pressure on migrants to conform to particular norms and values (Cederberg and Anthias 2006a). This is arguably a central feature of contemporary 'integration' approaches across much of Europe, where some have argued that a neo-assimilationist shift has been taking place (e.g. Joppke 2004, Kofman 2005). While this shift has been more apparent in some other countries, policies in Sweden have moved in a similar direction, and, more broadly, cultural 'othering' has shaped also the Swedish debate (e.g. Pred 2000, de los Reyes et al. 2003, Schierup et al. 2006). As part of that, the complexity of factors that result in ethnic divisions are downplayed in favour of an argument that points to the alleged tendency of migrants to isolate themselves and 'not integrate'.

When it comes to the discourse that emphasises individual responsibility and critiques 'passive' welfare policies, this provides an important part of the framework for Anita's narrative in particular. However, both interviewees generally emphasise agency and responsibility. Nina argues that individual effort is all that is required for success, and she continuously dismisses claims about 
discrimination. Anita similarly downplays discrimination as a potential factor, and makes a more general argument that migrants should take greater responsibility for their situation. This discourse sits within a broader ideological framework, centred on the argument that rights need to be accompanied by responsibilities. It problematizes what is seen as a paternalistic approach that makes migrants (and other marginalised groups) passive and welfare dependent, something we see clearly in the most recent government strategy for integration, 'Empowerment against exclusion' (Skr 2008/09:24). While particular expressions of this framework refer to migrants in particular, it is part of a broader political-economic transformation, strengthening the role of the market while reducing welfare support (e.g. Schierup et al. 2006) ${ }^{4}$. Furthermore, it rests on particular assumptions about the citizen/subject, seen to have choice and agency.

This takes us back to Rose's (1999) study of liberal subjectivity and how a conception of an autonomous, responsible and reflexive subject has come to dominate our understanding of ourselves, others and social relations. Rose illustrates how individuals are governed through various techniques but have come to see themselves as having choice and autonomy, which in turn implies a tendency to understand one's situation in terms of individual achievement or failure (whilst disregarding social constraints and structural explanations). Such self-conceptions are arguably particularly significant (and difficult to manage) in neo-liberal times. The combination of experiencing persistent insecurity and regarding one's situation as a result of personal achievement/failure could be seen characteristic of the neo-liberal subject (e.g. Phoenix 2004, Walkerdine 2003, see also Foucault 2008). While the extent of neo-liberal transformation differs between countries, Sweden's political economy has moved in such a direction since the mid-1980s, as noted earlier (e.g. Schierup et al. 2006, Schierup and Ålund 2011). The casualization of the labour force and welfare cutbacks in combination imply greater insecurity for individuals who are increasingly positioned as in charge of their personal situation (Cederberg and Anthias 2006a).

\section{Multiple readings: complexity, contradiction, and narrative as performance}

So far, I have focused on how public discourses frame migrant narratives and in particular highlighted the role they play in the normalisation of unequal power relations. However, I have also emphasised the fact that subjectivities and narratives are complex, and multiple readings are therefore important ${ }^{5}$. This includes the two narratives discussed here, which by no means can be reduced to public discourse. For instance, while Nina tended to blame problems on migrants, she also spoke of the negative aspects of living in a segregated neighbourhood. And while Anita attempted to confirm certain stereotypes of migrants 'taking advantage' and 'not making an effort', she also highlighted burdensome aspects of those, as such recognising some negative effects of generalisations on migrants. The latter forms an interesting example of a broader tendency in both narratives, where the women try to escape particular subjectivities while at the same time reproducing them by re-affirming 
the existence of a negatively loaded 'other', from which the narrated self is presented at a distance, to give a publicly 'acceptable' story of 'integration'.

Highlighting such complexity in narratives is important both theoretically and for ethical/political reasons. Notably, there is a need to avoid imposing a singular 'expert' reading by the researcher whilst devaluing the subject's own interpretation of events (e.g. Stivers 2009). At the same time, I have argued that it is important not to avoid critically examining certain narratives based on the fact that they are marginal (Haraway 1991). By doing so, one risks not only providing a limited account, but also reinforcing the 'truth' status of discourses reproduced by subjects on the margins (Popular Memory Group 1982). This is particularly problematic when those discourses themselves contribute to marginalisation, as in stories about migrants 'abusing the welfare state' or 'not making efforts to integrate'.

The argument for analysing how knowledge is situated brings us back to the idea of narrative as coconstruction and the importance of considering the interview context, the researcher's role and the performative dimension. The first point to make here is that the narratives were recounted in an interview with a white, Swedish, female researcher. Phoenix (1994) has discussed the issue of similarity/difference of interviewer/interviewee and argued that there are no simple answers in regard to the effect of ethnic, gender and class differences. My experience seems to confirm this, in particular regarding ethnicity. On the one hand, I suspect that some interviewees were unwilling to share some of their experiences with me because I am Swedish, which would have involved certain social pressures, including precisely the concern to present the self as a 'good migrant' and a 'well integrated' subject. On the other hand, at times it appeared to be easier for individuals to share certain experiences with a person outside of their ethnic/national community, as other social pressures were not present. The latter appeared particularly significant in interviews with women, highlighting the gendered nature of intra-ethnic power relations (Cederberg 2012). Another important point is that the interviews were carried out in Swedish rather than the migrants' first language. While this is likely to impose limits on certain aspects of their narratives, we may gain further insight into how migrants are positioned in Sweden by highlighting the how the Swedish language sets boundaries for their selfrepresentation.

I noted earlier a range of factors that appeared to impact on how narratives were constructed, and one issue I would like to highlight here concerns the class position of the two women. In some cases, downward social mobility appears to have produced rather critical accounts by interviewees, who are frustrated with their loss of social status through migration, but with Nina and Anita, we see a rather different reaction. Both women were seemingly in advantaged class positions prior to migration, and while they have, at face value, experienced downwards mobility, some contextual factors can help us 
understand how they evaluate their positions. For example, Nina seems to gain fulfilment from playing an important role in her local community through her work at the day centre, and the fact that Anita has a Swedish partner is likely to be important for how she constructs her story. Furthermore, what they both seem to share is an aim to uphold a certain social status by presenting themselves as successful, accepted, and not as victims of exclusion or discrimination. The latter could be perceived as something that only 'bad' migrants should suffer from, in line with the approach to subjectivity that emphasises the individual's power to influence his/her position.

\section{Concluding remarks}

As we have seen, biographical narratives are complex, multi-faceted and situated, and they need to be analysed as such, by highlighting tensions and contradictions, and by considering the interview context, the researcher's role and the performative aspects of narratives. The focus of this paper was on how public discourses constrain individual narratives, and by exploring how particular discourses of migrant integration and ethnic inequalities are taken up by migrants, I considered the normalising function of discourse, and argued for the importance of taking this into account when studying inequalities. Much of the discussion has focused on the idea of a responsible individual who has the power to influence his/her life situation, and I have suggested that this is central to 'common sense' conceptions of the subject today. I would like to briefly come back to this issue here and make a couple of points regarding the notion of agency.

First of all, a critique of the 'common sense' conception of the subject recounted above should not be taken to imply that there is no space for agency within the complex, fluid subjectivities (and narratives) I have argued for. Complex power configurations and the existence of different discourses provide space for choice and, at times, change (Davies and Harré 1990, Foucault 1979). However, it is important to conceive of agency not in essentialist terms, but as a possibility emerging for actors in certain positions at certain times and in certain contexts, or in Butler's (1995: 47) words, 'to question the conditions of its possibility not to take it for granted as an a priori guarantee'. From such a perspective, the popular conception of the subject described above over-emphasises what individuals can do, as well as the extent to which what they do is individually chosen rather than structurally produced (Davies 2000).

This takes me to my second point, which is that analysing the normalising function of discourses that rest upon such a conception of the subject can help us to highlight their constitutive properties. In turn, this can contribute to a de-naturalisation of the social identities and relations they re/produce, and may provide opportunities for conceiving (and shaping) those identities and relations differently (Davies 2000). Finally, by de-centring the individual as the key factor determining social experiences and positions, more attention can be paid to the structures that constrain individuals. As such, a detailed 
analysis of subjectivities should be seen not in terms of shifting focus away from broader social structures and power relations, but rather as a way to achieve insight into how those are shaped and reproduced.

\section{Bibliography}

Anthias, F (2002) 'Where do I belong?: Narrating collective identity and translocational positionality, Ethnicities, 2.

Apitzsch, U and Siouti, I (2007) Biographical Analysis as an Interdisciplinary Research Perspective in the Field of Migration Studies. Johann Wolfgang Goethe Universität, Frankfurt am Main.

Apitzsch, U and Inowlocki (2000) 'Biographical Analysis: A 'German' School?' in Chamberlayne, P, Bornat, $\mathrm{J}$ and Wengraf, $\mathrm{T}$ eds The turn to biographical methods in social science. Comparative issues and examples. London: Routledge.

Atkinson, P and Delamont, S (2006) 'Rescuing narrative from qualitative research', Narrative Inquiry, $16(1)$

Bertaux, D and Kohli, M (2009) 'The Life Story Approach: A Continental View', in Harrison, B ed Life Story Research. London: SAGE.

Bevelander P (1999) The employment integration of immigrants in Sweden. Journal of Ethnic and Migration Studies, 25(3).

Bevelander P (2005) The Employment Status of Immigrant Women: The Case of Sweden. International Migration Review, 39(1).

Breckner, R (2007) 'Case-Oriented Comparative Approaches: the Biographical Perspective as Opportunity and Challenge in Migration Research', in Schittenhelm, K (ed) Concepts and Methods in Migration Research. Conference Reader. Available at www.cultural-capital.net

Butler, J (1995) 'Contingent Foundations: Feminism and the Question of "Postmodernism", in Benhabib, S et al. Feminist Contentions. A Philosophical Exchange. London: Routledge.

Cederberg, M (2006) Everyday racism in Malmö, Sweden. The experiences of Bosnians and Somalis. Unpublished Doctoral Thesis. Nottingham Trent University. 
Cederberg, M and Anthias, F (2006a) 'Mapping of Policies and Policy Analysis - the Swedish case' Report WP 1, FeMiPol Project.

Cederberg, M and Anthias, F (2006b) 'National report: Key Informants Interviews - the Swedish case' Report WP 2, FeMiPol Project.

Cederberg, M (2012) 'Migrant networks and beyond: Exploring the value of the notion of social capital for making sense of ethnic inequalities', Acta Sociologica, 55(1).

Chamberlayne, P, Bornat, J and Wengraf, T eds (2000) The turn to biographical methods in social science. Comparative issues and examples. London: Routledge.

De los Reyes, P, Molina, I and Mulinari, D eds (2003) Maktens (o)lika förklädnader - kön, klass och etnicitet $i$ det postkoloniala Sverige. Stockholm: ATLAS förlag.

Davies, B (2000) A body of writing 1990-1999. AltaMira Press.

Davies, B and Harré, R (1990/2000) 'Positioning: The discursive production of selves' in Davies, B, A body of writing 1990-1999. AltaMira Press.

Eastmond, E (2007) 'Stories as Lived Experience: Narratives in Forced Migration Research', Journal of Refugee Studies, 20(2).

Erel, U (2007) 'Constructing Meaningful Lives: Biographical Methods in Research on Migrant Women', Sociological Research Online, 12(4)5.

Findlay, A M and Li F L N (1997) 'An auto-biographical approach to understanding migration: the case of Hong Kong emigrants', Area, 29(1).

Folkpartiet (2004) Utanförskapets Karta. En kartläggning över utanförskapet i Sverige. Stockholm: Folkpartiet.

Folkpartiet (2008) Utanförskapets Karta. Arvet efter Mona Sahlin. Stockholm: Folkpartiet.

Foucault, M (1977) Discipline and Punish: The Birth of the Prison. Harmondsworth: Penguin. 
Foucault, M (1979) The History of Sexuality Volume one: The Will to Knowledge. London: Penguin Books.

Foucault , M (1980) Power/Knowledge. New York: Pantheon.

Foucault, M (1988) 'Technologies of the self' in Martin, LH et al. Technologies of the Self: A Seminar with Michel Foucault. London: Tavistock.

Foucault, M (2008) The Birth of Biopolitics. Basingstoke: Palgrave Macmillan.

Goodson, I F (1992) ‘Studying Teachers' Lives: An Emergent Field of Inquiry', ed Goodson, I F, Studying Teachers' Lives. London: Routledge.

Goodson, I F (1995) 'The story so far: personal knowledge and the political', in eds Hatch and Wisniewski, Life History and Narrative. London: The Falmer Press.

Gubrium, J F and Holstein, J A (2002) 'From the Individual Interview to the Interview Society', in Gubrium, J F and Holstein, J A, Handbook of Interview Research. Context and Method. London: SAGE.

Halfacree, K H and Boyle, P (1993) 'The challenge facing migration research: the case for a biographical approach', Progress in Human Geography, 17(3).

Haraway, D (1991) Simians, Cyborgs and Women. London: Free Association Books.

Harrison, B (2009) 'Editor's Introduction: Researching Lives and the Lived Experience', in Harrison, B, Life Story Research. London: Sage, Volume 1.

Inowlocki, L and Lutz, H (2000) 'Hard Labour: The 'Biographical Work' of a Turkish Migrant Woman in Germany', European Journal of Women's Studies, 7(3).

Integrationsverket (2003) Rapport Integration 2002. Norrköping.

Johnson, R, Chambers, D, Raghuram, P and Tincknell, E (2004) The Practice of Cultural Studies. London: SAGE. 
Joppke, Christian (2004) 'The retreat of multiculturalism in the liberal state: theory and policy' in The British Journal of Sociology, 55(2).

Knocke W (1999) The Labour Market for Immigrant Women in Sweden: Marginalised Women in Low-valued Jobs. In Wrench J, Rea A and Ouali N (eds.) Migrants, Ethnic Minorities and the Labour Market. Integration and Exclusion in Europe. London: Macmillan.

Knocke W (2000) Integration or Segregation? Immigrant Populations Facing the Labour Market in Sweden. Economic and Industrial Democracy 21(3).

Kofman, E (2005) 'Citizenship, Migration and the Reassertion of National Identity', Citizenship Studies, 9(5).

Kontos, M et al. (2009) FeMiPol: Integration of Female Migrants in Labour Market and Society. Policy Assessment and Policy Recommendations. Final Report.

Lawson, V (2000) 'Arguments within Geographies of Movement: the theoretical potential of migrants' stories', Progress in Human Geography, 24(2).

Merrill, B and West, L (2009) Using Biographical Methods in Social Research. London: SAGE.

Miller, T (2005) Making sense of motherhood: a narrative approach. Cambridge: Cambridge University Press.

Miller, T (2007) '"Is This What Motherhood is All About?" Weaving Experiences and Discourse through Transition to First-Time Motherhood', Gender and Society, 21(3).

Moen, T (2006) 'Reflections on the Narrative Research Approach', International Journal of Qualitative Methods, 5(4).

Phoenix, A (1994) 'Practising Feminist Research: The Intersection of Gender and 'Race' in the Research Process, in Maynard, M and Purvis, J (eds) Researching Women's Lives from a Feminist Perspective. London: Taylor \& Francis.

Phoenix, A (2004) 'Neoliberalism and Masculinity: Racialization and the Contradictions of Schooling for 11- to 14-Year-Olds', Youth \& Society, 36:227. 
Phoenix, A (2009) 'De-colonising practices: negotiating narratives from racialised and gendered experiences of education', Race, Ethnicity and Education, 12(1).

Plummer, K (2001) 'The Call of Life Stories in Ethnographic Research', in Atkinson, Paul et al. (eds) Handbook of Ethnography. London: SAGE.

Popular Memory Group (1982) 'Popular memory: theory, politics, method', in Johnson, Richard et al. Making Histories: Studies in history-writing and politics. London: Hutchinson.

Pred, A (2000) Even in Sweden. Racisms, Racialized Spaces, and the Popular Geographical Imagination. Berkeley: University of California Press.

Roberts, B (2002) Biographical Research. Buckingham: Open University Press.

Rose, N (1999) Governing the soul. The shaping of the private self. $2^{\text {nd }}$ edition. London: Free Association Books.

Rosenthal, G (2004) 'Biographical research', in Seale, C et al., Qualitative Research Practice. London: SAGE.

Riessman, C K (2008) Narrative Methods for the Human Sciences. London: SAGE.

Rustin, M (2000) 'Reflections on the biographical turn in social science', in Chamberlayne, P, Bornat, $\mathrm{J}$ and Wengraf, $\mathrm{T}$ eds The turn to biographical methods in social science. Comparative issues and examples. London: Routledge.

Sangster, J (2009) 'Telling Our Stories: Feminist Debates and the Use of Oral History', in Harrison, B ed Life Story Research. London: SAGE.

Schierup, C and Ålund, A (2011) 'The end of Swedish exceptionalism? Citizenship, neoliberalism and the politics of exclusion', Race \& Class, 53.

Schierup, C, Hansen, P and Castles, S (2006) Migration, Citizenship, and the European Welfare State. A European Dilemma. Oxford: Oxford University Press.

Skrivelse 2008/09:24 Egenmakt mot utanförskap - regeringens strategi för integration. 
SOU 2006:79 Integrationens svarta bok. Agenda för jämlikhet och social sammanhållning. Slutbetänkande av Utredningen om makt, integration och strukturell diskriminering. Stockholm: Fritzes.

Stanley, L (1992) The auto-biographical I. The theory and practice of feminist auto/biography. Manchester: Manchester University Press.

Stivers, C (2009) 'Reflections on the Role of Personal Narrative in Social Research', in Harrison, B ed (2009) Life Story Research. London: SAGE.

Tamboukou, M (2003) Women, Education and the Self. Basingstoke: Palgrave Macmillan.

Taylor, S (2010) Narratives of Identity and Place. London: Routledge.

Taylor, S and Littleton, K (2006) 'Biographies in talk: a narrative-discursive research approach', Qualitative Sociology Review, 2(1).

Walkerdine, V (2003) 'Reclassifying Upward Mobility: Femininity and the neo-liberal subject', Gender and Education, 15(3).

Wengraf, T, Chamberlayne, P and Bornat, J (2002) 'A Biographical Turn in the Social Sciences? A British-European View', Cultural Studies/Critical Methodologies, 2(2).

Yuval-Davis, N and Kaptani, E (2009) 'Performing Identities: Participatory Theatre among Refugees', in Wetherell, M, Theorizing Identities and Social Action. Basingstoke: Palgrave Macmillan.

\section{Acknowledgements}

I would like to thank Leah Bassel, Bryan Mabee, Tina Miller and two anonymous reviewers for providing very useful comments and suggestions on earlier versions of the paper.

\section{Funding}

A number of interviews drawn on here were undertaken as part of the research project FeMiPol: Integration of female immigrants into labour market and society (2006-2008), funded by the Sixth Framework Programme of the European Commission, Scientific Support to Policies SSP4. The UK project team, directed by Prof. Floya Anthias, was responsible for the UK and Sweden country cases. 


\section{Biography}

Maja Cederberg is Senior Lecturer in Sociology at Oxford Brookes University, where she previously worked as a Post-Doctoral Researcher. Her research interests are in international migration, gender, ethnicity, 'race' and racism and social inequalities. Other related interests include work and employment, labour market and welfare policies, social theory and qualitative research methods.

\footnotetext{
${ }^{1}$ While arguably relevant to all qualitative research, a critical account of subjectivity is perhaps particularly important in research on life stories and/or identities, in relation to which an individualized conception of the subject has often been assumed.

${ }^{2}$ Aside from those interviews, the two research projects also included interviews with experts such as policy makers, civil servants, and NGO and trade union representatives, and analysis of public debates and policies on migration and integration.

${ }^{3}$ However, such constructions about Sweden have also in some cases contributed to a difficulty to acknowledge structural inequalities (Cederberg 2006).

${ }^{4}$ See also Schierup and Ålund (2011) for a discussion about inter-connections between integration policies and social and economic policies in the last two decades.

${ }^{5}$ I should also note that there is not a one-way relationship between public discourse and individual narratives, and that public discourse is neither static nor singular, but shifting and shaped by multiple influences.
} 